\title{
História pública de resistência quilombola: conexões e potencialidades do museu virtual em 3D do Quilombo do Cabula aplicado ao ensino de História
}

\author{
Public History of Quilombola Resistance: \\ Connections and Potentialities of the Virtual Museum \\ in 3D of the Cabula Quilombo Applied to History Teaching
}

Luciana Conceição de Almeida Martins*

Alfredo Eurico Rodrigues Matta ${ }^{* *}$

\section{RESUMO}

Os principais debates contemporâneos no campo do ensino de História instigam às conexões significativas entre presente e passado, a fim de proporcionar experiências dialógicas e construtivas das pesquisas historiográficas aplicadas ao ensino de História. Diante dessa constatação, o presente artigo tem por objetivo empreender uma discussão sobre a importância da trajetória da pesquisa sócio-histórica quilombola da localidade do Cabula, na cidade do Salvador, Bahia, e seus resultados para o desenvolvimento de um museu virtual em 3D, bem como demonstrar as potencialidades da sua aplicação no ensino de História. Para tal, utilizamos como embasamento teórico o movimento da história pública em uma abordagem socioconstrutivista, que propõe uma compreensão e conscientização histórica a partir da resolução de problemas de natureza aplicada.

Palavras-chave: História pública; Museu Virtual do Quilombo do Cabula; ensino de História.

\section{ABSTRACT}

The main contemporary debates in the field of History teaching instigate the significant connections between the present and the past, in order to provide dialogic and constructive experiences of historiographic research applied in the teaching of History. In view of this finding, the present article aims to discuss the importance of the quilombola sociohistorical research trajectory in Cabula, in the city of Salvador, Bahia, and its results for the development of a 3D virtual museum, as well as how to demonstrate the potential of its application in the teaching of History. To this end, we will use as a theoretical basis the movement of public history in a socio-constructivist approach, which proposes an understanding and historical awareness based on the resolution of problems of an applied nature.

Keywords: public history; Virtual Museum of the Quilombo Cabula; History teaching.

\footnotetext{
* Universidade do Estado da Bahia (UNEB), Salvador, BA, Brasil. luckianas@gmail.com

** Universidade do Estado da Bahia (UNEB), Salvador, BA, Brasil. alfredomatta@gmail.com
} 
Mais do que em qualquer outro ano deste século XXI, o momento contemporâneo de pandemia - ano de 2020 -, impõe-nos uma reflexão severa quanto à importância e uso das tecnologias digitais da informação e comunicação na educação. Quando direcionamos essa necessidade ao ensino de História, a preocupação se amplia, porque não mais cabe unicamente reproduzir conteúdos de maneira expositiva nas aulas remotas ou de educação à distância. Faz-se necessário o esforço do docente para efetivar a aplicação de metodologias ativas e criativas, baseadas em resolução de problemas e que instigue a concretude do conhecimento histórico.

No âmbito dos debates sobre ensino de História, urge a demanda pela implementação de reflexões críticas dos conteúdos, de maneira a estabelecer conexões imprescindíveis entre passado e presente, significando importantes pesquisas históricas produzidas no meio acadêmico, a fim de que os estudantes do ensino básico possam vivenciar experiências inusitadas e dialógicas, potencializadas pelas linguagens digitais.

Nesse contexto, projetos que envolvem jogos, escrita colaborativa, arquivos documentais em rede, museus virtuais, dentre outros, tornam-se realidades cada vez mais próximas das salas de aulas físicas e, principalmente, das que estão alocadas em espaços virtuais. A partir dessa compreensão, emerge o objetivo deste artigo que é empreender uma reflexão sobre a importância da trajetória da pesquisa sócio-histórica quilombola da localidade do Cabula na cidade do Salvador, Bahia, e seus resultados para o desenvolvimento de um museu virtual em 3D, bem como demonstrar as potencialidades da sua aplicação no ensino de História, embasado na dimensão da história pública.

Conforme se observa, este artigo propõe uma reflexão com base em três conexões: pesquisa historiográfica clássica, ensino de História e desenvolvimento de solução mediadora de aprendizagem, que neste estudo é o museu virtual do quilombo do Cabula, cujo link de acesso para download é: www. museudocabula.com.br. Diante dessa constatação, questionamos: como a historiografia clássica de uma comunidade quilombola que existiu em Salvador até o início do século XIX e que nos deixa um legado de memórias difíceis e sensíveis pode subsidiar o desenvolvimento da história pública no formato de museu virtual? Qual o modelo de museu virtual que atende à proposta socioconstrutivista? Quais as potencialidades quanto à aplicação do museu virtual do quilombo do Cabula no ensino de História?

Com base nos questionamentos, no primeiro momento, trabalharemos a 
história de resistência quilombola da localidade do Cabula do início do século XIX, respaldada em fontes históricas documentais e em referências bibliográficas, mas vislumbrando o desenvolvimento da história pública. Na sequência, estabeleceremos uma discussão associando a historicidade produzida com a proposta de desenvolvimento de um museu virtual socioconstrutivista e, por fim, apresentaremos as potencialidades da referida solução mediadora de aprendizagem para o ensino de História.

\section{A HISTÓRIA DE RESISTÊNCIA NEGRA DO QUILOMBO DO CABULA NA PERSPECTIVA DA HISTÓRIA PÚBLICA}

A localidade do Cabula é compreendida como uma extensa área que compõe o miolo da cidade do Salvador e que conecta vários bairros que se integram e se identificam no âmago da sua historicidade. A denominação de "miolo" refere-se à área situada geograficamente na parte central da cidade do Salvador, com extensão de 115 quilômetros, cuja delimitação atual "está entre a BR 324 e a Avenida Luiz Viana Filho, mais conhecida como Avenida Paralela, estendendo-se desde a invasão Saramandaia até o limite Norte do Munícipio" (FERNANDES e REGINA, 2005, p. 39), conforme podemos observar na figura que segue.

Atualmente, o grande Cabula encontra-se em ampla expansão urbanística e representa um importante vetor de desenvolvimento da cidade do Salvador, com sua expressiva densidade populacional, oferta de importantes serviços e intensa atividade comercial. Todavia, trata-se de uma urbanização recente, pois, até a década de 1950, a principal característica era de uma área ruralizada da cidade, cuja ocupação foi constituída inicialmente por índios, brancos pobres e negros resistentes ao sistema escravista, portanto, com pouca integração ao núcleo urbanizado. Posteriormente ocupado por roceiros produtores de laranjas, o território não perdeu o caráter de resistência negra dessas localidades (MARTINS, 2017). É sobre esse passado remoto de um Cabula quilombola que vamos refletir, pois a historicidade dessa comunidade que resistiu às agruras do sistema escravista inspirou o desenvolvimento do museu virtual em 3D.

Entende-se por quilombos os ajuntamentos que continham negros fugidos do sistema escravista (base estrutural socioeconômica do Brasil colonial). Tal compreensão é mais complexa do que considerá-los como comunidades 
Figura 1 - Espacialização do Miolo da Cidade do Salvador e do Cabula (área de estudo)

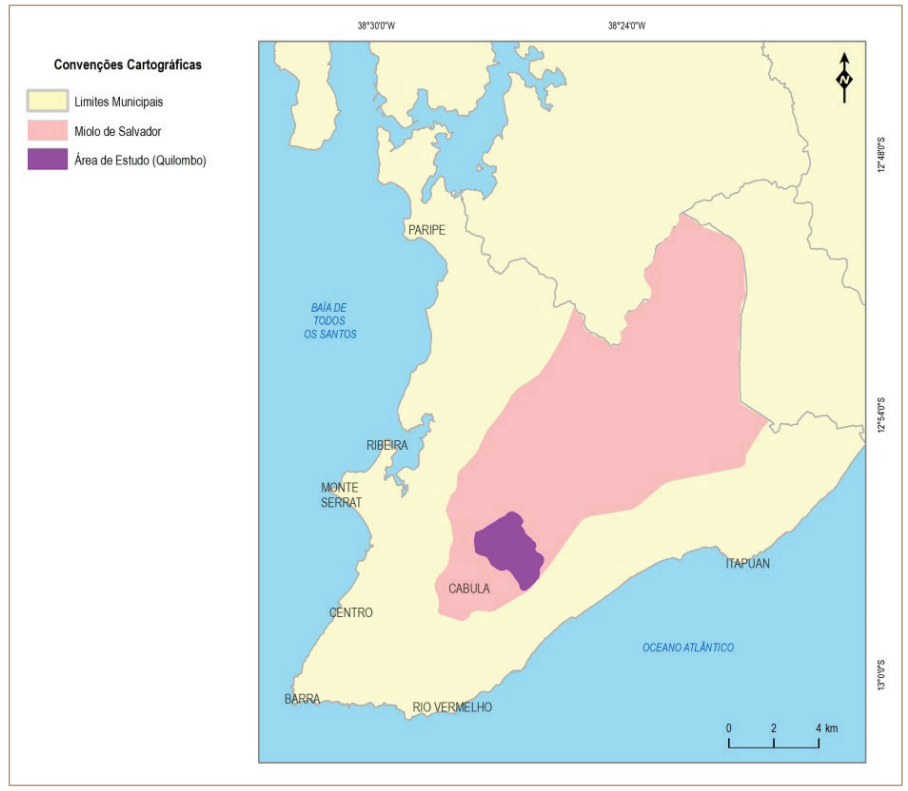

Fonte: Adaptado de Mascarenhas, 2008.

compostas apenas por negros fugitivos, pois a historiografia apresenta inúmeros casos de arraiais com residências de libertos, presença de desertores militares, indígenas e até de brancos pobres que, por acolherem negros fugidos, foram chamados de quilombos por senhores e autoridades dos períodos Colonial e Imperial, como ocorreu no exemplo da comunidade do Cabula (MARTINS, 2017).

As fontes documentais corroboram tal compreensão, uma vez que, em 6 de março de 1741, a coroa decretou, por meio do Conselho Ultramarino, uma provisão que passou a considerar todo e qualquer espaço que abrigasse mais de cinco escravizados fugitivos como quilombo, mesmo que estivessem situadas em áreas despovoadas, sem ranchos levantados ou pilões (BIBLIOTECA NACIONAL DE LISBOA, [1741] 2000). Não satisfeitos com a provisão real, em função do aumento das fugas de escravizados, autoridades locais decretaram leis provinciais que ordenavam ataques às localidades que abrigassem a partir de dois escravizados fugitivos (MATTOSO, 2003). 
Com as marcas do sistema escravocrata em voga e o consequente aumento e consolidação do tráfico de escravizados advindo do continente africano, ao longo dos séculos XVI, XVII, XVIII e XIX, a Capitania da Bahia se mostrou um território de ampla resistência negra. Não à toa, no entorno da cidade do Salvador, nos espaços ruralizados, constatamos variadas formações de quilombos (MARTINS, 2017). No caso específico do Cabula, acreditamos que o ajuntamento existia desde o final do século XVIII, uma vez que identificamos a preocupação das autoridades locais quando, no ano de 1780, o então governador D. Fernando José de Portugal nomeou, por meio de carta patente, o Sr. Severino da Silva Lessa para o cargo de Capitão de Entradas e Assaltos do Distrito do Cabula e demais freguesias como Pilar, Santo Antônio Além do Carmo - que já inclui a localidade -, Pirajá e Brotas, com o argumento de que era necessário "evitar-se os continuados roubos, que cometem os negros foragidos, não só dessa cidade, mas os dos engenhos do seu recôncavo, juntando-se para isso em quilombos, dos quais fazem as maiores hostilidades" (ARQUIVO HISTÓRICO ULTRAMARINO, 1788).

O denominado pelas autoridades coloniais como quilombo do Cabula foi desarticulado na noite do dia trinta de março de 1807. Na ocasião, pequenos núcleos comunitários compostos por negros libertos, escravizados fugidos dos seus senhores e raros brancos pobres, que viviam na grande área do Cabula, foram surpreendidos com o ataque da força militar baiana, extraordinariamente organizada para empreender a destruição dos quilombos localizados no entorno do centro urbano da cidade do Salvador, Bahia. (ARQUIVO HISTÓRICO ULTRAMARINO, 1807).

Neste início do século XIX, a vivência na localidade provavelmente não era fácil, uma área rústica, com Mata Atlântica densa e de difícil acesso para os que saíam do antigo centro urbanizado de Salvador, sem contar a tensão e ameaça de ataques dos capitães de entradas e assaltos, que representavam os anseios da elite senhorial e autoridades. Por outro lado, justamente por ser de difícil acesso e pela oferta natural de meios de sobrevivência, era uma localidade propícia para a formação de quilombo, até porque contava-se com presença de vales e, portanto, formação de rios, fundamentais para o sustento e subsistência dos arraiais com o fornecimento de água e alimentos para os habitantes. A mata também fornecia frutos e possibilitava caça (MARTINS, 2017). Em meio a tudo isso, havia uma tênue articulação de habitantes do Cabula com 
o núcleo urbano da cidade do Salvador, o que possibilitava certo dinamismo e trânsito de pessoas, além do abastecimento em relação às necessidades básicas como alimentos, vestuários, ferramentas para o trabalho, entre outros.

Diante do delicado aspecto geográfico e perfil social local, a missão arquitetada e articulada pelo governador D. João de Saldanha da Gama Mello e Torres Guedes de Brito, $6^{\circ}$ conde da Ponte, seguiu às ordens régias, que orientavam medidas cautelosas no processo de investigação dos ajuntamentos, para que o momento da destruição fosse preciso e eficiente (ARQUIVO PÚBLICO DO ESTADO DA BAHIA, 1803-1808, fl. 102-102v).

No processo investigativo, o conde da Ponte infiltrou homens da sua confiança a fim de vigiar negros e examinar prováveis locais, para descobrir rotas de fugas e acolhimentos de escravos fugidos (ARQUIVO PÚBLICO DO ESTADO DA BAHIA, 1803-1808, fl. 97-98). Ao constatar, sem dificuldades, as numerosas organizações de "quilombos" nas matas que cercavam a cidade, $o$ governador iniciou o plano de destruição.

Foram os relatos, a partir dessas investigações, que possibilitaram o desvelar de uma história de luta e resistência negra dos habitantes do Cabula contra as mazelas da escravidão, evidenciando estratégias de sobrevivência de um povo que subverteu os parâmetros impostos pela sociedade escravista, na busca de uma tênue liberdade. $\mathrm{O}$ fato foi rechaçado durante anos pela historiografia tradicional e, portanto, trata de memórias sensíveis, mas necessita alcançar públicos mais amplos, a fim de que se compreenda lutas afirmativas dos grupos negros do presente.

De acordo com os relatos presentes nas fontes documentais, produzia-se na localidade uma forma própria de garantia da existência. Não só pelo enfrentamento dos desafios perante uma natureza rústica, mas também por conta dos cultos aos ancestrais daqueles guerreiros, pela produção de remédios naturais e serviços de cura prestados a locais e a necessitados, que, mesmo sendo moradores da cidade, frequentavam a localidade (ARQUIVO HISTÓRICO ULTRAMARINO, 1807). Os festejos e celebrações regados a "danças, vestuários caprichosos", muita comida, momentos de bênçãos e orações, faziam parte da vivência dos residentes do local e, provavelmente, atraíam visitantes da cidade que ajudavam no quilombo para, em contrapartida, obter ganhos espirituais (ARQUIVO HISTÓRICO ULTRAMARINO, 1807).

As práticas sociais e culturais encontradas neste quilombo, que também 
remetiam à realidade de outras comunidades quilombolas, já abordadas pela historiografia, denotaram, segundo a concepção da elite senhorial, desrespeito às tradições culturais católicas, uma vez que poderia agregar povos de diversas nações africanas em uma lógica de crença que, se bem articulada, poderia gerar danos à sociedade escravocrata e fortalecimento no processo de resistência social dos negros. Nesse sentido, foram destacadas com desdém e repúdio pelo conde da Ponte, que os considerou rituais de "insultos à religião, ataques aos costumes e transgressões de todas as leis, ordens e solicitou providências para a conservação do sossego e tranquilidade publica" (ARQUIVO PÚBLICO DO ESTADO DA BAHIA, 1803-1808. fl. 97-98).

As fontes manuscritas indicaram a autêntica importância religiosa que os cultos de matriz africana praticados nesse quilombo representaram para os negros e brancos das camadas mais carentes. Foi o elo que articulou os quilombolas do Cabula a alguns habitantes da cidade, caracterizados pelas autoridades como: "vadios, supersticiosos, roubadores, criminosos, adoentados" e, possivelmente, facilitou a comunicação com outros ajuntamentos próximos (ARQUIVO HISTÓRICO ULTRAMARINO, 1807).

Em meio às investigações e suas narrativas, alguns personagens emergiram com força e liderança dos arraiais que compunham a grande área do Cabula, tais como: a escravizada Nicácia da França, o escravizado José, outro escravizado Zacarias, o crioulo Simão e a africana Quitéria do Sacramento.

Nicácia da França, considerada pelo historiador João José Reis (2008) uma sacerdotisa do quilombo do Cabula, foi julgada pelas autoridades como uma das líderes, que assumia a função de feiticeira local. Pesquisas realizadas pelo historiador, baseadas em fontes documentais e nos relatos do memorialista José Alvares do Amaral, apontam que era parda, de meia idade, aleijada dos pés, braços e se locomovia por meio de uma cama improvisada com rodas (REIS, 2008), provavelmente fabricada em madeira retirada do próprio local. As limitações físicas não nulificavam o respeito, admiração, reverência e até fama nutrida tanto pelos moradores dos arraiais do Cabula, quanto por residentes da cidade, uma vez que esta era respeitosamente procurada para que adivinhasse a sorte, uma possível vidente. Também atendia realizando outros trabalhos de cura espiritual, manuseando e demonstrando seus conhecimentos das ervas do local. Eram esses moradores da cidade que a sustentavam com o que necessitasse em troca de seus serviços religiosos (REIS, 2008). 
Sobre a fama de Nicácia na cidade, o autor José Álvares do Amaral, que vivenciou o contexto histórico da metade do século XIX e escreveu a obra Resumo Chronologico e Noticioso da Província da Bahia desde seu descobrimento em 1500, revela que as histórias que se divulgavam sobre seus feitos de "feitiçaria e sortilégios" eram impressionantes, de tal maneira, que no momento da sua prisão pelas tropas do conde da Ponte, esta foi submetida a um "desfile" de exibição, na qual atravessou presa em seu carro as ruas da cidade e foi acompanhada por "muito povo", conforme pode ser observado na citação que segue.

Morreu nesta cidade a celebre Nicacia, que tão falada foi por muito tempo, e da qual ainda hoje se referem factos interessantes. Constando ao Governador Conde da Ponte, que ela era muito feiticeira, mandou-a prender no Cabula, onde ela habitava e exercia suas feitiçarias e sortilégios, atravessando presa as ruas da cidade em um carro, por ser aleijada, sendo acompanhada de muito povo. (AMARAL, 2013, p. 128-129)

Indícios apontam que, após a execução da missão de desarticulação do quilombo, Nicácia pode ter morrido na prisão da cidade. Sobre José escravizado de F. e indicado como um dos líderes, a informação foi que exercia a função de assistente, construtor de novas casas. Segundo relato do governador, baseado nas investigações prévias, esse negro era o "encarregado de cortar os paus para os arcos que intentavam fazer" (ARQUIVO PÚBLICO DO ESTADO DA BAHIA, 1803-1808, fl. 123). O relato instiga a interpretação de que o Cabula já se configurava como um "quilombo", ou melhor, arraiais "consolidados", cuja proporção territorial de ocupação negra era razoável, isso considerando a quantidade de casas construídas e em processo de construção.

Zacarias era escravizado do senhor Inácio de Arruda Pimentel, comerciante da cidade do Salvador. Esse negro também figurou como importante integrante do arraial do Cabula, exercendo os cargos de escrivão e secretário. Escrevendo os possíveis planos de futuras ações da comunidade, em escrita, cujos caracteres foram próprios da sua nação de origem, dificultando assim a decifração pelas autoridades (ARQUIVO PÚBLICO DO ESTADO DA BAHIA, 1803-1808, fl. 123).

No processo de devassa, após a tentativa de destruição dos quilombos e aprisionamento de negros suspeitos, o Desembargador Ouvidor Geral do Cri- 
me, Cláudio Jozé Pereira, enviou uma carta à coroa lusitana, datada de oito de maio de 1807, na qual aponta como líderes, além de Nicácia da França, Simão, um crioulo e residente nas terras do Campo Seco, e a africana Quitéria do Sacramento, moradora das terras dos padres bentos. (ARQUIVO PÚBLICO DO ESTADO DA BAHIA, 1807, fl. 198). Todas as localidades apontadas ficam no Cabula.

A história do quilombo do Cabula não terminou com a irrupção perpetrada pelas autoridades políticas da cidade. O temor e ameaça dos ajuntamentos de negros fugidos ainda pairava no ar da sociedade escravagista soteropolitana do início do século XIX. Após a força tarefa que desarticulou, momentaneamente, os ajuntamentos do entorno da cidade do Salvador, o cuidado nas decisões do pós-invasão foi redobrado e o governador conde da Ponte acompanhou, cobrando com rigor as atitudes punitivas aos negros encontrados. Os homens aprisionados nos quilombos foram conduzidos ao Arsenal e empregados nas obras reais, enquanto as mulheres foram encaminhadas à cadeia da cidade (ARQUIVO HISTÓRICO ULTRAMARINO, 1807).

Conforme se nota, os variados aspectos advindos do aprofundamento dessa pesquisa histórica clássica fornecem importantes subsídios para uma produção colaborativa em alusão à difusão e democratização do conhecimento histórico. Quando mencionamos a pesquisa histórica clássica, estamos nos referindo a todo processo de pesquisa que envolve o método pautado na problematização de acordo com os objetivos e questionamentos do pesquisador, investigações e análises a partir do mergulho em busca de respaldo bibliográfico e nas fontes históricas documentais pesquisadas em arquivos e institutos especializados e também por meio da oralidade e relatos de memórias, quando possível.

Em geral, o resultado desse tipo de pesquisa histórica é difundido nos ambientes acadêmicos, por meio de publicações de artigos em periódicos, livros etc. São produções imprescindíveis para o campo da História, mas de que adianta o desenvolvimento de textos magníficos sobre trajetórias nacionais, regionais ou locais, se o âmbito do ensino de História -e mesmo a sociedade -, não tiver acesso ou não compreender a publicação, dado o teor de complexidade demandado pelo campo científico?

Com base neste questionamento, diagnosticamos uma importante pendência a ser sanada pelo campo histórico, uma vez que, na maioria dos casos, 
as ricas produções de cunho mais teórico atendem às discussões intradisciplinares, sendo valorizado o caráter das superespecializações, no qual cabe ao pesquisador escolher recortes sempre mais restritos da realidade sobre os quais concentram seus estudos. Paralelo a isso, acreditamos que tais pesquisas, muito mais que a possibilidade de uma narrativa e problematização, oportunizam inúmeras possibilidades de desenvolver soluções mediadoras de aprendizagens a fim de potencializar o conhecimento e ensino de História, seja no formato de histórias em quadrinhos, games, trilhas históricas interpretativas para alunos, preservação de arquivos, centros de memória/memoriais, produção de vídeo, documentários, podcast, blogues, rádio escolar ou em museus virtuais (como foi a proposta deste artigo), entre outros.

O estudo sobre o quilombo do Cabula contou com todo arsenal possível à investigação histórica, de maneira que conseguisse auxiliar na modelagem do museu virtual, isto é, produções bibliográficas, fontes históricas levantadas no Arquivo Público do Estado da Bahia (APEB), no Arquivo Histórico Ultramarino (AHU), no Arquivo Digital da Biblioteca Nacional, entre outros institutos. Além disso, foram imprescindíveis os depoimentos de antigos comunitários da localidade sobre as primeiras ocupações e disposição da área antes dos primeiros sinais de urbanização. Outro auxílio foi de cartogramas históricos, que, comparados aos depoimentos e fontes mencionadas anteriormente, subsidiaram a constituição de um consistente acervo para o design, modelagem e desenvolvimento do museu virtual em 3D.

Do contexto historiográfico, foi aproveitado o conjunto de informações sobre os aspectos da natureza local, aspectos sociais da vivência no quilombo, os principais personagens e suas funções. No que se refere aos aspectos da natureza local, foram modeladas as matas densas com árvores frutíferas, possíveis produções agrícolas locais, animais, rios etc. Da vivência e dinâmica social no quilombo, foram representados os momentos de festejos, farta alimentação, cultos de matriz africana aos ancestrais, produção de remédios naturais, serviços de curas e outros, além dos personagens que foram destacados como possíveis líderes e suas respectivas funções em meio à vivência na comunidade.

Ora, ficou clara a intenção de significar essa pesquisa e representá-la no formato digital. Não obstante, no campo historiográfico, o principal embasamento para pesquisas intencionalmente direcionadas ao desenvolvimento de 
soluções mediadoras de aprendizagens é a história pública. O campo da história pública favorece o movimento dialógico, pois é o elo que articula as ricas pesquisas históricas clássicas com a comunidade e o ensino, até alcançar públicos mais amplos. Quando se enfatiza o caráter dialógico da história pública, faz-se necessário elucidar que se trata do encontro das múltiplas vozes produzindo a construção do conhecimento histórico (MARTINS, 2017). Essas vozes refletem a práxis e articulações não somente entre o ambiente acadêmico e o não acadêmico, mas também entre o presente e passado. São questões que implicam em uma nova configuração sobre a compreensão da História e do papel do historiador. Assim, a História não se reduz ao estudo e construções sobre o passado, mas das possíveis relações entre passado e presente nos seus devidos contextos de épocas (MARTINS, 2009).

Diante do exposto, concorda-se com o historiador Jairo Antônio Melo Floréz (2014, p. 75), ao afirmar que "a história pública é aquela focada no mundo real, com seus problemas concretos” em que se busca, sobretudo, a resolução de problemas por meio de uma abordagem da história aplicada. Conforme discutimos anteriormente neste artigo, isso não significa dizer que essa dimensão nega a historiografia clássica com os processos metodológicos já consolidados e respaldados em levantamentos bibliográficos, cruzamentos e análises de fontes históricas variadas, sínteses e escrita problematizadora relacionada ao tema delimitado. Além desses encaminhamentos comuns ao historiador, são acrescidos princípios de comprometimento com questões que orientam à busca por "justiça social, ativismo e do fortalecimento das comunidades" (FLORÉZ, 2014, p. 76).

O historiador público é aquele que assume uma postura praxiológica, sendo o mediador do conhecimento que é construído em colaboração. Sendo assim, este adquire a postura profissional que tem por função instigar a reflexão e a consciência histórica para um público mais amplo, isto é, não acadêmico. Seus principais desafios são: construir coletivamente e interdisciplinarmente, motivar sujeitos sociais na busca pela reflexão sobre sua própria história, empreender a relação entre passado e presente de maneira que o primeiro assuma um autêntico significado e construir caminhos para que a história clássica possa ter espaços e públicos ampliados, bem como encontrar inovadoras formas e usos do conhecimento histórico (ALMEIDA e ROVAI, 2011). Em síntese, a história pública é uma dimensão de construção coletiva 
da história que se conecta ao desenvolvimento de um museu virtual socioconstrutivista, como pode ser acompanhado a seguir.

\section{MUSEU VIRTUAL COMO FERRAMENTA COGNITIVA DE CONSTRUÇÃO E DIFUSÃO DO CONHECIMENTO HISTÓRICO}

Entende-se por museus virtuais de caráter socioconstrutivista os espaços de mediação conectados em rede que proporcionam a concretização de ações museológicas como a socialização de acervos ou coleções digitais, experimentos de vivências em contextos e situações sociais que poderão ser conflituosas, ou não, tanto do passado quanto do presente, e aspectos da cultura de grupos sociais. Sua virtualização privilegia a comunicação, de tal maneira que a interatividade se torna parte integrante dessas ações. Nesse sentido, aquele sujeito que visita o museu não assumirá apenas a postura de visitante, mas de participante ou colaborador, como discutiremos adiante (MARTINS, 2017).

De acordo com a museóloga e doutora em ciência da informação Diana Farjalla Correia Lima (2009), a concepção de museu virtual acompanha o atual momento de avanços das tecnologias da informação e comunicação e possibilita novas propostas de experiências e vivências para um público visitante mais amplo e diversificado.

No caso específico do museu virtual em 3D sobre o quilombo do Cabula, além dos importantes elementos advindos da pesquisa historiográfica, tais como as construções de simulações dos contextos de Salvador no início do século XIX, do espaço do quilombo, das relações sociais de conflitos e resistência negra do passado, de aspectos da cultura e vivência da comunidade pertencente aos arraiais do Cabula, buscou-se, sobretudo, o desenvolvimento de uma ferramenta cognitiva, isto é, uma solução que pudesse mediar as aprendizagens, não só divulgando e informando sobre os acervos levantados, mas também fornecendo suporte para a exposição dos conhecimentos prévios e trocas de saberes. Em outras palavras, um espaço com efetiva interatividade, dialogicidade e colaboração.

A interatividade é a modalidade comunicacional que emerge da mediação dos seres humanos entre si e com o meio. Neste caso, amplia-se a antiga lógica da distribuição (transmissão) da informação, em que vigorava a proposta de ligação unilateral emissor-mensagem-receptor, para a lógica da reciproci- 
dade, em alusão à construção do conhecimento (SILVA, 2004). Corroborando essa concepção, Carvalho e Matta (2008) concebem a interatividade como

a intersecção de ações e práticas sociais dos sujeitos, que, ao terem uma prática qualquer de vida comum, a coletivizam e a torna a própria expressão e vivência da interatividade como contexto comum da interpessoalidade, da coletividade composta pela ação construtiva de um sujeito não individual. (CARVALHO e MATTA, 2008, p. 3)

Para melhor compreender a efetividade da interatividade no campo educacional, Marco Silva (2004) destaca três princípios essenciais. O primeiro é que o emissor deve pressupor a participação no sentido de intervenção do receptor e, com isso, ressalta-se que participar não é somente responder "sim" ou "não", mas modificar e interferir na mensagem. O segundo é um complemento do primeiro, pois defende a construção em coautoria, isto é, concebe o "emissor como um receptor em potencial e o receptor como emissor em potencial” (SILVA, 2004. p. 7). O terceiro diz respeito aos questionamentos/mensagens, os quais não devem ser fechados, oferecendo, assim, possibilidades de amplas conexões, associações e significações por parte dos que interagem.

Com base nessa perspectiva, um museu virtual que demanda o princípio socioconstrutivista e, com este, a característica comunicacional da interatividade, defende critérios imprescindíveis, que deverão estar implicados desde o pensar do design da produção museológica, como a elaboração de ações que instiguem a efetiva participação dos visitantes como coautores da produção. Também com a elaboração de questionamentos direcionados à resolução de problemas, a fim de motivar reflexões, pesquisas e, sobretudo, posturas críticas quanto ao conhecimento histórico. Outro aspecto do museu socioconstrutivista é a dialogicidade, que ocorre no momento em que as diferentes vozes, mesmo falando de espaços e temporalidades diferenciadas, comunicam-se em determinado ambiente, ocasionando o encontro de sujeitos e seus complexos cognitivos.

A colaboração é caracterizada pelo engajamento mútuo dos sujeitos em um esforço para a solução de um problema em comum. É o compartilhamento dos saberes e da própria existência. Isso não implica a ausência da cooperação, ou seja, divisão de trabalho entre os participantes, contudo não se perde de vista um trabalho que envolve o todo (MARTINS, 2009). Espinosa (2003) 
define alguns pressupostos imprescindíveis ao trabalho colaborativo, como habilidades comunicativas dos participantes; técnicas interpessoais; relações simétricas e recíprocas; desejos de compartilhar a resolução da tarefa (responsabilidade individual no alcance do êxito do grupo). Não por acaso, o trabalho colaborativo demanda a participação de todos os envolvidos no processo de construção em condição de igualdade, isto é, todos são protagonistas nesta proposta de pesquisa ativa.

Em suma, quando falamos em interatividade, dialogismo e colaboração não mencionamos apenas os elementos que estão presentes na versão atualizada do museu, mas principalmente na participação da comunidade local e de diferentes especialistas no processo de concepção e desenvolvimento, em um encontro das diferentes vozes (MATTA, 2014). Trata-se, assim, de um aporte fundamentado no socioconstrutivismo vygotskyano e no dialogismo e polifonia bakhtianos porque, como foi abordado, abandona-se a proposta de transmissão unidirecional de informações pela troca interativa entre os sujeitos engajados. Em meio a essa compreensão, é possível destacar possibilidades e potencialidades do referido museu virtual no ensino de História, que serão trabalhadas no tópico que segue.

\section{CONEXÕES E POTENCIALIDADES PARA APLICAÇÃO DO MVQC NO ENSINO DE HISTÓRIA}

Tomando por base as discussões sobre a história de resistência negra e quilombola da comunidade do Cabula e seu embasamento teórico a partir do campo da história pública, bem como a compreensão sobre o desenvolvimento de um museu virtual socioconstrutivista, iremos, neste tópico, refletir sobre as conexões e potencialidades para aplicação do MVQC no ensino de História.

É imperioso ressaltar que muitas escolas públicas da cidade do Salvador, por meio do trabalho individual de professores de História, já fazem uso do referido museu virtual. Embora o museu tenha o enfoque na luta de resistência presente na comunidade quilombola do Cabula no início do século XIX, a respeitada contextualização da pesquisa conduz a apresentação de muitos aspectos da vivência dos povos negros libertos que sobreviveram no entorno do centro urbanizado da cidade, em áreas ruralizadas e pouco exploradas comercialmente. Nesse sentido, temas relacionados às camadas sociais, questão da água e abastecimento em Salvador no século XIX, noção espacial da cidade, 
religiosidade, cultura baiana de matriz africana, resistência negra, entre outros, poderão ser abordados e refletidos pelo professor de História e de outros componentes curriculares.

Outras características fornecem a noção das possíveis conexões entre as Tecnologias Digitais da Informação e Comunicação (TIDIC), que neste artigo é o museu virtual, com a pesquisa e ensino de História, o que nos leva a defender que o MVQC tem como potencialidades:

- Imersão histórica e diálogos entre sujeitos do século XXI com personagens do século XIX. Isso significa que a visita ao MVQC proporciona vivências, trocas de saberes e percepções de sujeitos do presente com ambientes, situações, contextos, coleções e personagens históricos. Nesse caso, sendo utilizada uma simulação em 3D, aproxima e, de fato, media o diálogo entre visitantes do presente e personagens e cenários do passado. Destarte, os diálogos e informações fornecidos pelos personagens do quilombo ajudam a solidificar o processo de interação e imersão.

- Proporciona ao participante/aluno uma relação inusitada com o tempo e espaço, a fim de romper barreiras de ordem geográfica, sem necessitar de deslocamento para um espaço físico específico. Pode-se acessar/ visitar, imergir e ajudar a construir histórias sem sair do próprio espaço de convívio e na hora disponível, pois a virtualidade possibilita essa flexibilidade.

- Reflexão e problematização histórica, uma vez que, durante todo o trajeto, o estudante pode parar para tentar refletir e solucionar questões problemas que são apresentadas com intuito de instigar a pesquisa e os ricos debates no campo da História.

- Interação e interatividade, pois oferece ao estudante e visitante em geral estratégias e espaços de interação e até mesmo de construção coletiva, incitando um "autoconhecimento", de acordo com os grupos ou sujeitos visitantes. Isso significa que o antigo formato de museus enquanto espaço de transmissão de informações está, paulatinamente, dando lugar à colaboração. Ou seja, o visitante/aluno não se comporta apenas como um observador, mas também interage e participa do enriquecimento do acervo com contribuições significativas, legitimando assim a ferramenta enquanto cognitiva. 
- Possibilita ao professor trabalhar com análise de fontes históricas em sala de aula, tais como imagens e documentos oficiais transcritos do início do século XIX, que foram socializados no percurso do museu.

- É acessível para professores que trabalham em instituições com dificuldades ou ausência de conexão com a internet. Para ter acesso ao museu, é preciso realizar o download, logo o professor pode levar em um laptop e exibir com ajuda de um projetor de multimídias.

Por fim, abre-se espaço para discussões sobre preservação da memória e do patrimônio cultural. Conforme mencionado neste artigo, trabalhou-se com a concepção de museu virtual socioconstrutivista, embasado pela dimensão da história pública e com abordagem vista de baixo, porque não se ressaltaram os acontecimentos heroicos dos grandes personagens nacionais, nem tampouco os acervos das autoridades ou representantes das camadas dominantes da população brasileira e baiana. A simulação realizada teve como aporte a vivência de pessoas simples, oprimidas e periferizadas pelo processo de segregação social da Bahia do século XIX e seus hábitos e lutas pela sobrevivência em meio ao contexto.

\section{CONSIDERAÇÕES FINAIS}

Este artigo teve como finalidade empreender uma reflexão sobre a importância da trajetória da pesquisa sócio-histórica quilombola e seus resultados para o desenvolvimento de um museu virtual em 3D socioconstrutivista, embasado pela dimensão da história pública, bem como demonstrar as possibilidades de reflexão e utilização deste museu virtual no ensino de História.

Ao problematizar sobre a comunidade quilombola do Cabula e mergulhar no contexto histórico de resistência negra da Bahia colonial no arvorecer do século XIX, foi possível organizar um rico acervo que revelou importantes temáticas para a discussão histórica em sala de aula, que são difíceis e sensíveis a determinados grupos sociais da contemporaneidade, mas que possibilitam uma ampla reflexão que pode vir a contribuir com as concepções afirmativas de superação e respeito às diferenças socioculturais, tais como: contradições e tensões entre as camadas sociais, religiosidade, a questão da água e abastecimento da cidade no século XIX, noções geo-históricas, cultura baiana de matriz africana, história local, entre outras.

Para conseguir reunir o conhecimento construído a partir da historiogra- 
fia clássica e organizá-los no formato de museu virtual socioconstrutivista em 3D, foi imprescindível pensar e atuar sob a lógica colaborativa da história pública, pois essa possibilita a queda de fronteiras, a difusão das informações em âmbito mundial, multiplicando e interconectando as fontes de conhecimentos em trabalhos que agregam a utilização de multimídias, como: som, imagens, textos, inclusive as mídias clássicas, dependendo apenas da criatividade, criticidade e raciocínio, tanto da pesquisadora quanto dos visitantes, que também são coautores.

Com base nessa perspectiva, a construção do conhecimento poderá ser realizada a partir do engajamento dos sujeitos no processo de aprendizagem, na medida em que as ideias e os conceitos apresentados obtiverem aplicabilidade em problemas vivenciados na realidade prática. Não obstante, defendemos que a aplicação do museu virtual do quilombo do Cabula no ensino de História, integrado a um projeto pedagógico consistente e consciente, pode potencializar múltiplas aprendizagens e o despertar do aluno para a conscientização histórica sobre o contexto presente. Além disso, poderá também contribuir para um movimento que conclama o ativismo social e a preservação do patrimônio e da memória.

\section{REFERÊNCIAS}

ALMEIDA, Juniele R.; ROVAI, Marta G. O. Apresentação. In: Introdução à história pública. São Paulo: Letra e Voz, 2011. p. 08-15.

AMARAL, José Álvares do. Resumo Chronologico e noticioso da Província da Bahia desde seu descobrimento em 1500. V. I. Lauro de Freitas - Ba. Livro.com, 2013. (Coleção Tempo Antigo: Memórias da História da Bahia).

CARVALHO, Ana Verena; MATTA, A. E. R. Interatividade - definindo o conceito para educação contextualizada e socio-construtivista. In: $14^{\circ}$ Congresso Internacional de Educação a Distância da ABED, 2008, Santos. Mapeando o impacto da EAD na cultura do ensino/aprendizagem. São Paulo: Associação Brasileira de Educação a Distância, 2008.

ESPINOSA, Maria Paz Prendes (2003) "Aprendemos... ¿Cooperando o colaborando? Las claves del método." In: SÁNCHEZ, Francisco Martínez (Org.) Redes de comunicación en la enseñanza - las nuevas perspectivas del trabajo corporativo. Barcelona: Paidós, p. 95-127.

FERNANDES, R.B; REGINA, M.E. A Segregação Residencial em Salvador no Contex- 
to do Miolo da Cidade. Cadernos do Logepa, João Pessoa, vol. 4, n. 1, p. 39-46, 2005.

FLORÉZ, Jairo Antônio Melo. Presentación. História 2.0: Conocimiento Histórico en Clave Digital. Bucaramanga, año IV, n.8. p. 75. dez de 2014.

LIMA Diana Farjalla Correia. O que se pode denominar como Museu Virtual segundo os museus que assim se apresentam... In: FREIRE, G. H. A. (Org.). A responsabilidade social da Ciência da Informação - ENANCIB 2009 (10) Encontro Nacional de Pesquisa em Ciência da Informação.. 1ed.João Pessoa: Ideia; ANCIB, 2009, v., p. 2451-2468.

MARTINS, Luciana Conceição de Almeida. Colaboração, tecnologia e ensino de História: o pensar histórico e a autoria de hipermídia em rede.2009. 137f. Dissertação (Mestrado em Educação e Contemporaneidade). Universidade do Estado da Bahia, Salvador, 2009.

MARTINS, Luciana Conceição de Almeida. História Pública do Quilombo Cabula: Representações de resistência em museu virtual 3D aplicada a mobilização do turismo de base comunitária. Tese (Doutorado Multi-Institucional e Muldisciplinar em Difusão do Conhecimento). Universidade Federal da Bahia. Faculdade de Educação da Bahia, Salvador/Ba, 2017.

MASCARENHAS, A. Análise do Processo de Uso e Ocupação do Solo da Avenida São Rafael - Salvador/BA. 2008. 180f. Dissertação (Mestrado em Engenharia Ambiental Urbana - MEAU). Escola Politécnica, Universidade Federal da Bahia.

MATTOSO, Kátia M de Queirós. Ser escravo no Brasil. Tradução James Amado. São Paulo: Brasiliense, 2003.

MATTA, Alfredo Eurico Rodrigues. Novas Linguagens para a História. Revista do Instituto Histórico e Geographico Brazileiro, v. 175, p. 267-290, 2014.

REIS, João José. Domingos Sodré, um sacerdote africano: escravidão, liberdade e candomblé na Bahia do século XIX. São Paulo: Companhia das Letras, 2008.

SILVA, Marco. Indicadores de interatividade para o professor presencial e on-line. Revista Diálogo Educacional (PUCPR), Curitiba - Paraná, v. 4, n.12, p.93-109, 2004.

\section{FONTES HISTÓRICAS MANUSCRITAS E IMPRESSAS}

ARQUIVO HISTÓRICO ULTRAMARINO (AHU). C. A. Cx. 71, n. 13.649 - 13.650. Ano 1788.

ARQUIVO HISTÓRICO ULTRAMARINO (AHU). Conselho Ultramarino. Brasil-Bahia. Cx. 149. n. 29815. Ano 1807. 
ARQUIVO PÚBLICO DO ESTADO DA BAHIA (APEB). Setor Colonial. Cartas à várias autoridades, no 163. Ano 1803 - 1808, fl. 102 - 102v.

ARQUIVO PÚBLICO DO ESTADO DA BAHIA (APEB), Cartas a várias autoridades, n. 163. Ano 1803-1808. fl. 97-98.

ARQUIVO PÚBLICO DO ESTADO DA BAHIA (APEB). Cartas a várias autoridades, n. 163. Ano 1803-1808, fl. 123.

ARQUIVO PÚBLICO DO ESTADO DA BAHIA (APEB). Correspondência expedida para o rei, n. 144. Ano 1807, fl. 198.

BIBLIOTECA NACIONAL DE LISBOA. Provisão de 6 de março de 1741. Legislação, sem cota apud LARA, Silvia Hunold. Legislação sobre escravos africanos na América portuguesa, In: GALLEGO, José Andrés (Coord.), Nuevas aportaciones a la história jurídica de Iberoamerica. Madri: Fundação Histórica Tavera/ Digibis/ Fundacíon Hernando de Larramendi, 2000 (CD-ROM).

Artigo submetido em 30 de outubro de 2020. Aprovado em 28 de janeiro de 2021. 